Stanisław KLUSEK

Piotr DUDKIEWICZ

Paweł KAMIŃSKI

Sylwia MANDZIAK

Celsa Huta Ostrowiec Sp. z o.o.

Mariusz ADAMCZYK

Piotr RÓŻAŃSKI

Ireneusz SZYPUŁA

Bogdan ZDONEK

Artur ŻAK

\title{
OPTIMISATION OF THE TECHNOLOGY OF SMELTING AND REFINING OF STEEL INTO HOT ROLLED SECTIONS ON AN INNOVATIVE PRODUCTION LINE
}

\author{
OPTYMALIZACJA TECHNOLOGII WYTAPIANIA I RAFINACJI STALI \\ NA KSZTAETOWNIKI GORĄCO WALCOWANE W INNOWACYJNEJ \\ LINII PRODUKCYJNEJ
}

\begin{abstract}
Experimental investigations have been carried out to optimise the secondary steel treatment technology in a ladle in order to ensure the required quality of steel intended for hot rolling of sections on an innovative line, with a reduced number of rolling stands characterised by a higher intensity of plastic processing. Experimental heats were made according to various steel deoxidation variants during secondary treatment and continuous casting of two steel grades. Continuous ingots were used to hot roll sections of various cross-sectional sizes. Based on the results of metallurgical, microscopic and mechanical tests of the sections, guidelines for the optimal continuous ingot production technology for hot rolling of sections on an innovative production line were developed.
\end{abstract}

Keyroords: low alloy steel, deoxidation, secondary metallurgy, mechanical properties, surface defects

\begin{abstract}
Przeprowadzono badania dośriadczalne nad optymalizacja technologii pozapiecowej obróbki stali w kadzi w celu zapewnienia roymaganej jakości stali przeznaczonej do walcowania na goraco ksztattowników w innowacyjnej linii, przy zmniejszonej liczbie klatek walcowniczych, charakteryzujacej się większa intensywnościa przerobu plastycznego. Wykonano doświadczalne wytopy wedtug różnych wariantów odtleniania stali w czasie pozapiecowej obróbki i ciagtego odlewania dwóch gatunków stali. $Z$ wlewków ciagtych odwalcowano na goraco ksztattowniki o różnej wielkości przekroju poprzecznego. Na podstawie wyników badań metaloznawczych, mikroskopowych $i$ właściwości mechanicznych ksztaltowników opracowano wytyczne do optymalnej technologii produkcji wlewków ciagtych do walcowania na goraco ksztattowników w innowacyjnej linii produkcyjnej, z wyeliminowaniem drutu Al woprowadzanego do krystalizatora w procesie ciagtego odlewania stali.
\end{abstract}

Stowa kluczowe: stal niskostopowa, odtlenianie, metalurgia pozapiecowa, właściwości mechaniczne, wady powierzchniowe

\section{INTRODUCTION}

Celsa "Huta Ostrowiec" Sp. z o.o. produces medium-sized sections in the process of hot rolling of continuous ingots with cross-sections of $200 \times 240$ and $220 \times 280 \mathrm{~mm}^{2}$ from low-carbon and low-alloy steels in two grades, namely S355J2 and S235JR/S275JR. The steel is smelted in an 140-tonne arc furnace, deoxidised with carbon (in the initial phase of the tapping), silicon and manganese during the tapping, refined and finished in a ladle furnace, followed by

Corresponding Author: bogdan.zdonek@imz.pl casting with a 6-strand CC machine without steel stream shielding with a inert gas between the tundish and concast mould. In the refining process, the liquid steel is deoxidised with $\mathrm{Si}$ and $\mathrm{Mn}$, and the $\mathrm{Al}$ content is maintained at a low acceptable level for trouble-free casting with the CC machine through metering nozzles, without the stream shield. The unit cost of continuous ingots production is significantly lower than that of aluminium-deoxidised steels in the refining process, however, hot rolled products are characterised by lower plastic properties, particularly impact strength at low temperatures. To ensure the required plastic properties of finished products, the steel is processed by continuously introducing an $\mathrm{Al}$ wire into the concast mould. 
Surface defects occurring on the sections, where high stresses occur in the rolling process - usually in the feet indicate the presence of complex clusters of non-metallic inclusions containing oxides and aluminium nitrides, and even elemental aluminium. The results of preliminary tests showed that the immediate cause of this type of defects are disturbances during the introduction of the $\mathrm{Al}$ wire into the mould in the continuous steel casting process.

As part of the implementation of the innovative process of hot rolling of sections with a reduced number of rolling stands, experimental investigations were carried out to optimise the secondary metallurgy technology in a ladle in order to partially or completely eliminate steel treatment with an $\mathrm{Al}$ wire in the mould or eliminate surface defects of the sections caused by steel processing with the $\mathrm{Al}$ wire.

Since the beginning of the 1990s, austenite grain refinement was used in order to obtain the required high impact properties in steels without aluminium, by creating acicular ferrite nucleating on small complex oxide inclusions with precipitates on them during solidification in an MnS crystalliser [1-4]. The effect of acicular ferrite formation is increased by introducing micro-additions of elements such as: $\mathrm{Ti}, \mathrm{V}, \mathrm{Nb}, \mathrm{Ce}, \mathrm{Zr}$ into the steel, forming very fine oxides or nitrides with lattice constants similar to the lattice constant of $\mathrm{MnS}$ precipitating on them [5-12]. This also increases the resistance of the steel to the cracking of welds in the heat affected zone, especially when welding thick sections.

\section{METHODOLOGY}

Table 1 presents the required chemical compositions of steel intended for sections according to the PN-EN 10025 standard and compositions determined by the manufacturer of the sections - Celsa Huta Ostrowiec. Table 2 lists the ranges of required mechanical properties of finished products made from these steels.

In order to meet the high purity requirements for steel subjected to hot plastic working in the conditions of high reduction of cross-sections for each steel grade, further restrictions on the following elements were introduced: $\mathrm{Sn}$ $\max 0.027 \%$, Ca - approx. $0.0020 \%$, O max - 0.004\%; N approx. $-0.009 \%$ and $\mathrm{H} \max -0.0005 \%$.
Table 2. Required mechanical properties of products made from the tested steel grades according to PN-EN 10025

Tabela 2. Wymagane właściwości mechaniczne wyrobów badanych gatunków stali wg PN-EN 10025-2:2005

\begin{tabular}{|c|c|c|c|c|}
\hline \multirow[b]{2}{*}{$\begin{array}{l}\text { Steel } \\
\text { grade }\end{array}$} & \multirow{2}{*}{$\begin{array}{c}\text { Yield strength } \\
{[\mathrm{MPa}]}\end{array}$} & \multirow{2}{*}{$\begin{array}{c}\text { Tensile strength } \\
{[\mathrm{MPa}]}\end{array}$} & \multicolumn{2}{|c|}{ Impact energy } \\
\hline & & & $\begin{array}{l}\mathrm{KV} \\
{[\mathrm{J}]}\end{array}$ & $\begin{array}{c}\boldsymbol{T} \\
{\left[{ }^{\circ} \mathrm{C}\right]}\end{array}$ \\
\hline S355J2 & 355 & $510-680$ & 27 & -20 \\
\hline S235JR & 235 & $360-510$ & 27 & 20 \\
\hline S275JR & 275 & $430-580$ & 27 & 20 \\
\hline
\end{tabular}

In order to ensure the required high strength properties and impact strength in the S355J2 steel sections at $-20^{\circ} \mathrm{C}$, a vanadium microadditive was added to its composition, forming $\mathrm{V}(\mathrm{CN})$ precipitates limiting the austenite grain growth during heating for rolling, and increasing the strength properties as a result of precipitation strengthening [2-4]. The effective action of vanadium in steel ensures the presence of dissolved aluminium, affecting grain refinement. The required $\mathrm{Al}$ content, amounting to a minimum of $0.012 \%$, is higher than the acceptable $\mathrm{Al}$ content in the liquid steel cast with the use of the metering nozzle method with a CC machine (0.003 and $0.006 \%$ respectively). Therefore, aluminium in the form of a wire is introduced into the concast mould of the $\mathrm{CC}$ machine continuously during steel casting. Irregularities in the wire introduction, consisting in repelling the wire from the axis toward the walls of the concast mould, cause its trapping in the frozen crystals zone or even adherence to the walls of the concast mould, oxidation and drawing into the solidifying ingot exiting the concast mould. This results in surface defects of the sections during rolling.

In order to eliminate the defects in the sections, improve the purity of the steel and provide the required plastic properties (impact strength) to the sections, actions were taken to use initial deoxidation of the steel with aluminium added to the stream separately and with other additives during tapping into the ladle. The scope of the tests included the production of experimental heats and their casting both without adding $\mathrm{Al}$ to the mould as well as with the introduction of the $\mathrm{Al}$ wire during casting of the heat on six strands.

Secondary oxidation of steel streams takes place during the continuous casting of steel intended for sections, from the tundish to the moulds without shielding the streams with inert gas. The oxidised surface of the liquid steel, as a result of turbulence in the mould, flows out in the form of

Table 1. Chemical compositions of steel for sections according to the PN-EN 10025-2:2005 standard and defined by the manufacturer, weight \%

Tabela 1. Składy chemiczne stali na kształtowniki według PN-EN 10025-2:2005 i ustalone przez wytwórcę kształtowników, \% masowe

\begin{tabular}{|c|c|c|c|c|c|c|c|c|c|c|c|c|c|}
\hline \multirow{2}{*}{\multicolumn{2}{|c|}{ Steel grade }} & \multicolumn{12}{|c|}{ Chemical composition of steel } \\
\hline & & \multirow{2}{*}{$\begin{array}{c}\mathbf{C} \\
\max \\
0.20\end{array}$} & \multirow{2}{*}{$\begin{array}{l}\text { Mn } \\
\max \\
1.60\end{array}$} & \multirow{2}{*}{$\begin{array}{c}\mathbf{S i} \\
\max \\
0.55\end{array}$} & \multirow{2}{*}{ 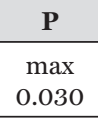 } & \multirow{2}{*}{$\begin{array}{c}\mathbf{S} \\
\max \\
0.030\end{array}$} & \multirow{2}{*}{$\begin{array}{c}\mathrm{Cr} \\
-\end{array}$} & \multirow{2}{*}{$\begin{array}{c}\mathbf{N i} \\
-\end{array}$} & \multirow{2}{*}{$\begin{array}{c}\text { Mo } \\
-\end{array}$} & \multirow{2}{*}{$\begin{array}{c}\mathrm{Cu} \\
\max \\
0.55\end{array}$} & \multirow{2}{*}{$\begin{array}{c}\text { Al } \\
-\end{array}$} & \multirow{2}{*}{$\begin{array}{l}\mathbf{V} \\
-\end{array}$} & \multirow{2}{*}{$\begin{array}{l}\mathbf{C}_{\mathbf{E}}{ }^{3} \\
\max \\
0.45\end{array}$} \\
\hline \multirow[b]{2}{*}{ S355J2 } & $\begin{array}{l}\text { PN-EN 10025- } \\
2: 2005\end{array}$ & & & & & & & & & & & & \\
\hline & manufacturer & 0.11 & 1.40 & 0.25 & 0.025 & 0.015 & 0.20 & 0.20 & 0.05 & 0.40 & $\begin{array}{c}\max \\
0.003^{1} \\
0.012^{2}\end{array}$ & $\begin{array}{l}\max \\
0,09\end{array}$ & $\begin{array}{l}\max \\
0.45\end{array}$ \\
\hline \multirow{2}{*}{$\begin{array}{l}\text { S235JR/ } \\
\text { S275JR }\end{array}$} & $\begin{array}{l}\text { PN-EN 10025- } \\
2: 2005\end{array}$ & $\begin{array}{c}\max \\
0.17 / \\
0.21 \\
\end{array}$ & $\begin{array}{c}\max \\
1.40 / \\
1.50 \\
\end{array}$ & - & $\begin{array}{c}\max \\
0.040\end{array}$ & $\begin{array}{c}\max \\
0.040\end{array}$ & - & - & - & $\begin{array}{l}\max \\
0.55\end{array}$ & - & - & $\begin{array}{l}\max \\
0.35\end{array}$ \\
\hline & manufacturer & $\begin{array}{l}0.09 \\
0.11^{3}\end{array}$ & $\begin{array}{l}0.90 \\
1.06^{3}\end{array}$ & 0.20 & 0.030 & 0.030 & 0.20 & 0.20 & 0.05 & 0.40 & $\begin{array}{c}\max \\
0.006^{1} \\
0.012^{2}\end{array}$ & - & $\begin{array}{l}\max \\
0.35\end{array}$ \\
\hline \multicolumn{14}{|c|}{$\begin{array}{l}\text { 1) Content of metallic aluminium in liquid steel and/or section's material } \\
{ }^{2)} \text { Content of metallic aluminium in the section's material } \\
{ }^{3)} \text { Values proposed on the basis of the analysis of 'peritectic sensitivity' of steel [1] with simultaneous fulfilment of the required carbon equivalent } \\
\text { calculated per the following formula: } \mathrm{C}_{\mathrm{E}}=\mathrm{C}+\mathrm{Mn} / 6+(\mathrm{Cr}+\mathrm{Mo}+\mathrm{V}) / 5+(\mathrm{Ni}+\mathrm{Cu}) / 15\end{array}$} \\
\hline
\end{tabular}


a slag film to the surface, mainly due to the precipitation and outflow of gas bubbles. The bubbles leave a slag film on the surface of the metal, which is crushed in the process of rolling into individual inclusions, containing $\mathrm{FeO}, \mathrm{MnO}, \mathrm{SiO}_{2}$, $\mathrm{Al}_{2} \mathrm{O}_{3}$ and $\mathrm{AlN}$, resulting from the treatment of steel with the $\mathrm{Al}$ wire in the mould. The solidification point of these inclusions is similar to or greater than the solidification point of steel. The effect of the bubbles emerging is the subsequent formation of slag film capillaries on the surface, described in detail by J. Campbell [5]. As a result of solidification of liquid steel in the mould, they form whirls moving along the solidifying surface of the ingot's shroud, detected under the microscope as reams. In the process of rod rolling, they usually flake and form scale, whereas in the process of intensive processing, which takes place in the case of section rolling, these inclusions, occurring at grain boundaries, initiate the formation of cracks that develop where stresses accumulate, most commonly in the foot.

The occurrence of such defects can be prevented by lowering the temperature of the precipitation of non-metallic inclusions, introducing a small amount of boron into the steel, allowing the formation of low melt slag, easily separating from the steel.

Due to the high and rising price of ferrovanadium, an attempt was made to replace at least half of it in steel with $\mathrm{Nb}$ in the form of ferroniobium.

Tables 3 and 4 present the methods of deoxidation, refining of steel in a ladle furnace and continuous casting of experimental smelting tests in steels S235JR/S275JR and S355J2 respectively, cast as one or several heats in a sequence.

Table 3. Method of deoxidation and refining of steel S235/275JR and processing of steel with an Al wire in a crystalliser in standard heats (No. 538999) and experimental heats

Tabela 3. Sposób odtleniania i rafinacji stali S235/275JR oraz obróbki stali drutem Al w krystalizatorze w wytopach standardowych (nr 538999) i wytopach doświadczalnych

\begin{tabular}{|c|c|c|c|c|c|c|c|c|c|}
\hline \multirow{3}{*}{ Test No. } & \multirow{3}{*}{ Heat No. } & \multirow{3}{*}{$\begin{array}{l}\text { Steel deoxidation and refining } \\
\text { method }\end{array}$} & \multirow{3}{*}{$\begin{array}{l}\text { Number of } \\
\text { heats in } \\
\text { a sequence }\end{array}$} & \multicolumn{6}{|c|}{$\begin{array}{l}\text { Introduction of Al wire into the crystalliser: } \\
\text { "+" - yes; "-" - no }\end{array}$} \\
\hline & & & & \multicolumn{6}{|c|}{ Strand number } \\
\hline & & & & $\mathbf{1}$ & 2 & 3 & 4 & 5 & 6 \\
\hline 1 & 538999 & $\begin{array}{l}\text { Standard, Si deoxidation at the } \\
\text { tapping }\end{array}$ & 1 & + & + & + & + & + & + \\
\hline 2 & 540351 & $\begin{array}{l}\text { Al deoxidation at the tapping and } \\
\text { Fe-B addition to the steel }\end{array}$ & 1 & - & + & + & + & + & + \\
\hline 3 & 540769 & $\begin{array}{l}\text { Al deoxidation at the tapping } \\
\text { Fe-B add. }\end{array}$ & 1 & - & + & + & + & + & + \\
\hline 4 & 542105 & $\begin{array}{l}\mathrm{Al} \text { deoxidation at the tapping and } \\
\text { Fe-B addition to the steel }\end{array}$ & \multirow[t]{2}{*}{2} & - & - & - & + & + & + \\
\hline 4 & 542104 & $\mathrm{Al}$ deoxidation at the tapping & & - & - & - & + & + & + \\
\hline 5 & $\begin{array}{l}544253 \\
544254 \\
544255\end{array}$ & Fe-B additive & 3 & - & - & - & - & - & - \\
\hline 6 & $\begin{array}{l}545800 \\
545801 \\
545802\end{array}$ & $\mathrm{Al}$ deoxidation at the tapping & 3 & - & - & - & - & - & - \\
\hline 9 & $\begin{array}{l}551812 \\
551813 \\
551814 \\
551815 \\
551816 \\
551817\end{array}$ & $\begin{array}{l}\text { Al deoxidation with the remaining } \\
\text { additives at the tapping }\end{array}$ & 6 & - & - & - & - & - & - \\
\hline
\end{tabular}

Table 4. Method of deoxidation and refining of steel S355J2 and processing of steel with an Al wire in a mould in conventional (No. 551948, 552180) and experimental heats

Tabela 4. Sposób odtleniania i rafinacji stali S355J2 oraz obróbki stali drutem Al w krystalizatorze w wytopach konwencjonalnych (nr 551948, 552180) i doświadczalnych

\begin{tabular}{|c|c|c|c|c|c|c|c|c|c|}
\hline \multirow{3}{*}{ Test No. } & \multirow{3}{*}{ Heat No. } & \multirow{3}{*}{$\begin{array}{l}\text { Steel deoxidation and refining } \\
\text { method }\end{array}$} & \multirow{3}{*}{$\begin{array}{l}\text { Number of } \\
\text { heats in } \\
\text { a sequence }\end{array}$} & \multicolumn{6}{|c|}{$\begin{array}{l}\text { Introduction of } \mathrm{Al} \text { wire into the crystalliser: } \\
\text { "+" - yes; "-" - no }\end{array}$} \\
\hline & & & & \multicolumn{6}{|c|}{ Strand number } \\
\hline & & & & 1 & 2 & 3 & 4 & 5 & 6 \\
\hline 5 & 544229 & Fe-B additive & 1 & - & - & - & - & - & - \\
\hline 7 & $\begin{array}{l}547831 \\
547832 \\
547833\end{array}$ & $\mathrm{Al}$ deoxidation at the tapping & 3 & - & - & - & - & - & - \\
\hline 8 & $\begin{array}{l}551791 \\
551792 \\
551793 \\
551794 \\
\end{array}$ & $\begin{array}{l}\mathrm{Al} \text { deoxidation with the remaining } \\
\text { additives at the tapping, } \\
\text { with the addition of } \mathrm{Fe}-\mathrm{Nb}\end{array}$ & 4 & - & - & - & + & + & + \\
\hline $\mathrm{P}$ & 551948 & Standard & 1 & + & + & + & + & + & + \\
\hline $\mathrm{P}$ & 552180 & Standard & 1 & + & + & + & + & + & + \\
\hline
\end{tabular}

$\mathrm{P}$ - comparative heat 
Due to the focus on microscopic examination of sections with surface defects, due to the steel deoxidation method, appropriate experimental and standard heats were selected. Standard steel heats were cast without using aluminium deoxidation during the release and secondary treatment, and their casting was carried out using the addition of aluminium in the form of a wire in the mould. In turn, experimental steel heats were cast into using aluminium deoxidation with simultaneous introduction of boron ferro-alloys at the tapping or without deoxidising the steel with aluminium at the tapping but with the use of boron ferro-alloy. The experimental heats were cast without and with the introduction of aluminium in the form of a wire into the moulds on selected strands.

In order to determine the causes of defects, as well as to assess the morphology of non-metallic inclusions and the general purity of steel from the sections from test and comparative heats, steel samples for microscopic examination and determination of total oxygen in the steel were taken from sections with surface defects. Standard investigation of mechanical properties of sections from both experimental and comparative heats were also performed in order to develop assumptions for the optimal section production technology.

Tables 5 and 6 summarise the content of elements characterising the purity of steel $\left(\mathrm{O}_{\mathrm{c}}, \mathrm{S}\right), \mathrm{Al}$ and $\mathrm{N}$ content as well as $\mathrm{B}, \mathrm{V}$ and $\mathrm{Nb}$ content in tested sections from test heats, for the S235/275JR and S355J2 grade respectively.

Samples were taken from continuous ingots and rolled sections for microscopic examination according to the diagrams shown in Fig. 1 and 2.

The examination of non-metallic inclusions was carried out using an Olympus light microscope and Inspect F scanning microscope equipped with an EDS detector for analysis of chemical composition in micro-areas. The quantitative analysis of non-metallic inclusions was carried out on met-

Table 5. Content of elements characterising the purity of steel $\left(\mathrm{O}_{\mathrm{c}}, \mathrm{S}\right)$, content of $\mathrm{Al}$ and $\mathrm{N}$ as well as $\mathrm{B}$ in tested sections from experimental heats for the S235/275JR grade

Tabela 5. Zawartości pierwiastków charakteryzujących czystość stali $\left(\mathbf{O}_{\mathrm{c}}, \mathbf{S}\right)$, zawartości Al i N oraz B w badanych kształtownikach z wytopów doświadczalnych dla gatunku S235/275JR

\begin{tabular}{|c|c|c|c|c|c|c|c|}
\hline \multirow[b]{2}{*}{ Test No. } & \multirow[b]{2}{*}{ Heat No. } & \multirow[b]{2}{*}{ Steel deoxidation and refining method } & \multicolumn{5}{|c|}{ Element content } \\
\hline & & & $\begin{array}{c}\mathbf{O}_{\mathbf{c}} \\
{[\mathrm{ppm}]}\end{array}$ & $\begin{array}{c}\mathbf{N} \\
{[p p m]}\end{array}$ & $\begin{array}{c}\text { Al } \\
{[\%]}\end{array}$ & $\begin{array}{c}\mathbf{S} \\
{[\%]}\end{array}$ & $\begin{array}{c}\text { B } \\
{[\%]}\end{array}$ \\
\hline 1 & 538999 & standard, Si deoxidation at the tapping & 36 & 107 & 0.011 & 0.015 & $<0.001$ \\
\hline 2 & 540351 & $\begin{array}{l}\text { Al deoxidation at the tapping and Fe-B addition to } \\
\text { the steel }\end{array}$ & 38 & 101 & 0.003 & 0.008 & 0.001 \\
\hline 3 & 540769 & $\mathrm{Al}$ deoxidation at the tapping, Fe-B addition & 27 & 95 & 0.011 & 0.013 & 0.0025 \\
\hline 4 & 542105 & $\begin{array}{l}\text { Al deoxidation at the tapping and } \\
\text { Fe-B addition to the steel }\end{array}$ & $\begin{array}{l}37 \\
41\end{array}$ & $\begin{array}{l}91 \\
95\end{array}$ & $\begin{array}{l}0.009 \\
0.002\end{array}$ & $\begin{array}{l}0.008 \\
0.007\end{array}$ & $\begin{array}{l}0.0014 \\
0.0017\end{array}$ \\
\hline 4 & 542104 & Al deoxidation at the tapping & $\begin{array}{l}37 \\
28\end{array}$ & $\begin{array}{l}96 \\
96\end{array}$ & $\begin{array}{l}0.010 \\
0.002\end{array}$ & $\begin{array}{l}0.014 \\
0.010\end{array}$ & $\begin{array}{l}<0.001 \\
<0.001\end{array}$ \\
\hline 5 & $\begin{array}{l}544253 \\
544254 \\
544255\end{array}$ & Fe- $\mathrm{B}$ additive & $\begin{array}{l}34 \\
51\end{array}$ & $\begin{array}{c}88 \\
103\end{array}$ & $\begin{array}{l}0.002 \\
0.002\end{array}$ & $\begin{array}{l}0.010 \\
0.013\end{array}$ & $\begin{array}{c}0.0019 \\
0.002\end{array}$ \\
\hline 6 & $\begin{array}{l}545800 \\
545801 \\
545802\end{array}$ & Al deoxidation at the tapping & $\begin{array}{l}36 \\
30 \\
50 \\
\end{array}$ & $\begin{array}{l}90 \\
86 \\
91 \\
\end{array}$ & $\begin{array}{l}0.003 \\
0.003 \\
0.003 \\
\end{array}$ & $\begin{array}{c}0.009 \\
0.008 \\
0.011 \\
\end{array}$ & $\begin{array}{l}<0.001 \\
<0.001 \\
<0.001\end{array}$ \\
\hline 9 & $\begin{array}{l}551812 \\
551813 \\
551814 \\
551815 \\
551816 \\
551817\end{array}$ & $\begin{array}{l}\text { Al deoxidation with the remaining additives at the } \\
\text { tapping }\end{array}$ & $\begin{array}{l}32 \\
32 \\
32 \\
32\end{array}$ & $\begin{array}{c}90 \\
100 \\
80 \\
110 \\
90 \\
90\end{array}$ & $\begin{array}{l}0.0037 \\
0.0039 \\
0.0039 \\
0.0038 \\
0.0039 \\
0.0042\end{array}$ & $\begin{array}{l}0.012 \\
0.015 \\
0.013 \\
0.017 \\
0.011 \\
0.013\end{array}$ & $\begin{array}{l}<0.001 \\
<0.001 \\
<0.001 \\
<0.001 \\
<0.001 \\
<0.001\end{array}$ \\
\hline
\end{tabular}

Table 6. Content of elements characterising the purity of steel $\left(\mathrm{O}_{\mathrm{c}}, \mathrm{S}\right)$, content of $\mathrm{Al}$ and $\mathrm{N}$ as well as $\mathrm{B}, \mathrm{V}$ and $\mathrm{Nb}$ in tested sections from experimental heats for the S355J2 grade

Tabela 6. Zawartości pierwiastków charakteryzujących czystość stali $\left(\mathrm{O}_{\mathrm{c}}, \mathrm{S}\right)$, zawartości Al i N oraz B, V i Nb w badanych kształtownikach z wytopów doświadczalnych dla gatunku S355J2

\begin{tabular}{|c|c|c|c|c|c|c|c|c|c|}
\hline \multirow[b]{2}{*}{ Test No. } & \multirow[b]{2}{*}{ Heat No. } & \multirow[b]{2}{*}{ Steel deoxidation and refining method } & \multicolumn{7}{|c|}{ Element content } \\
\hline & & & $\begin{array}{c}\mathbf{O}_{\mathrm{c}} \\
{[\mathrm{ppm}]}\end{array}$ & $\begin{array}{c}\mathbf{N} \\
{[p p m]}\end{array}$ & $\begin{array}{c}\text { Al } \\
{[\%]}\end{array}$ & $\begin{array}{c}\mathbf{S} \\
{[\%]}\end{array}$ & $\begin{array}{c}\text { B } \\
{[\%]}\end{array}$ & $\begin{array}{l}\mathbf{V} \\
{[\%}\end{array}$ & $\begin{array}{l}\mathrm{Nb} \\
{[\%]}\end{array}$ \\
\hline 5 & 544229 & Fe-B additive & 51 & 93 & 0.008 & 0.013 & 0.0017 & 0.08 & - \\
\hline 7 & $\begin{array}{l}547831 \\
547832 \\
547833 \\
\end{array}$ & $\mathrm{Al}$ deoxidation at the tapping & $\begin{array}{l}31 \\
34 \\
33 \\
\end{array}$ & $\begin{array}{l}87 \\
86 \\
94 \\
\end{array}$ & $\begin{array}{l}0.003 \\
0.003 \\
0.003 \\
\end{array}$ & $\begin{array}{l}0.012 \\
0.012 \\
0.012 \\
\end{array}$ & $\begin{array}{l}<0.001 \\
<0.001 \\
<0.001\end{array}$ & $\begin{array}{l}0.08 \\
0.08 \\
0.08 \\
\end{array}$ & $\begin{array}{l}- \\
- \\
-\end{array}$ \\
\hline 8 & $\begin{array}{r}551791 \\
551792 \\
551793 \\
551794 \\
\end{array}$ & $\begin{array}{l}\text { Al deoxidation with the remaining additives } \\
\text { at the tapping, with the addition of } \mathrm{Fe}-\mathrm{Nb}\end{array}$ & $\begin{array}{l}30 \\
29 \\
27 \\
33 \\
\end{array}$ & $\begin{array}{c}90 \\
100 \\
90 \\
80 \\
\end{array}$ & $\begin{array}{l}0.0033 \\
0.0044 \\
0.0040 \\
0.0047 \\
\end{array}$ & $\begin{array}{l}0.014 \\
0.010 \\
0.011 \\
0.011 \\
\end{array}$ & $\begin{array}{l}<0.001 \\
<0.001 \\
<0.001 \\
<0.001\end{array}$ & $\begin{array}{l}0.04 \\
0.04 \\
0.04 \\
0.04 \\
\end{array}$ & $\begin{array}{l}0.018 \\
0.020 \\
0.020 \\
0.021 \\
\end{array}$ \\
\hline $\mathrm{P}$ & 551948 & Standard & & 85 & 0.003 & 0.010 & $<0.001$ & 0.041 & 0.019 \\
\hline $\mathrm{P}$ & 552180 & Standard & & 86 & 0.003 & 0.020 & $<0.001$ & 0.07 & 0.002 \\
\hline
\end{tabular}

$\mathrm{P}$ - comparative heat 
allographic microsections of longitudinal samples cut from the sections' feet. The analysis of the inclusions was carried out with the Metilo software.

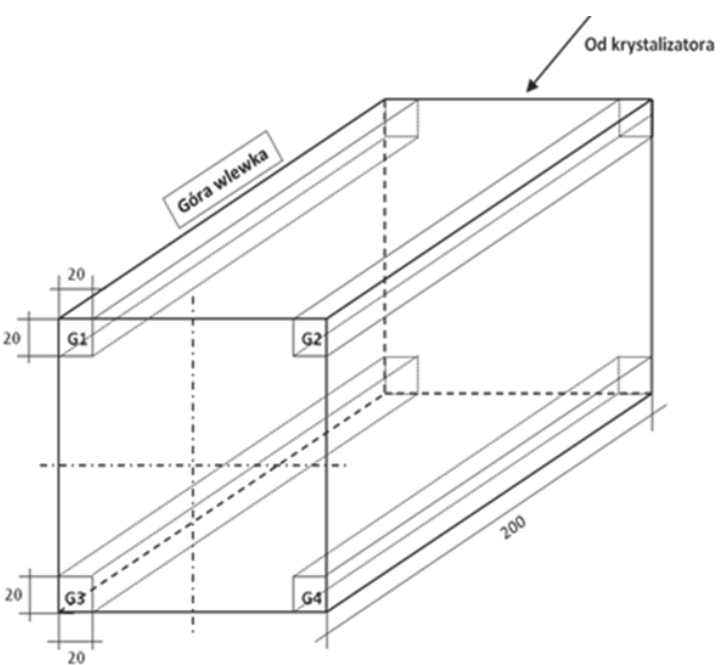

Fig. 1. Dimensions and diagram of cutting samples from the corners of the continuous ingot

Rys. 1. Wymiary oraz schemat wycinania próbek z naroży wlewka ciągłego
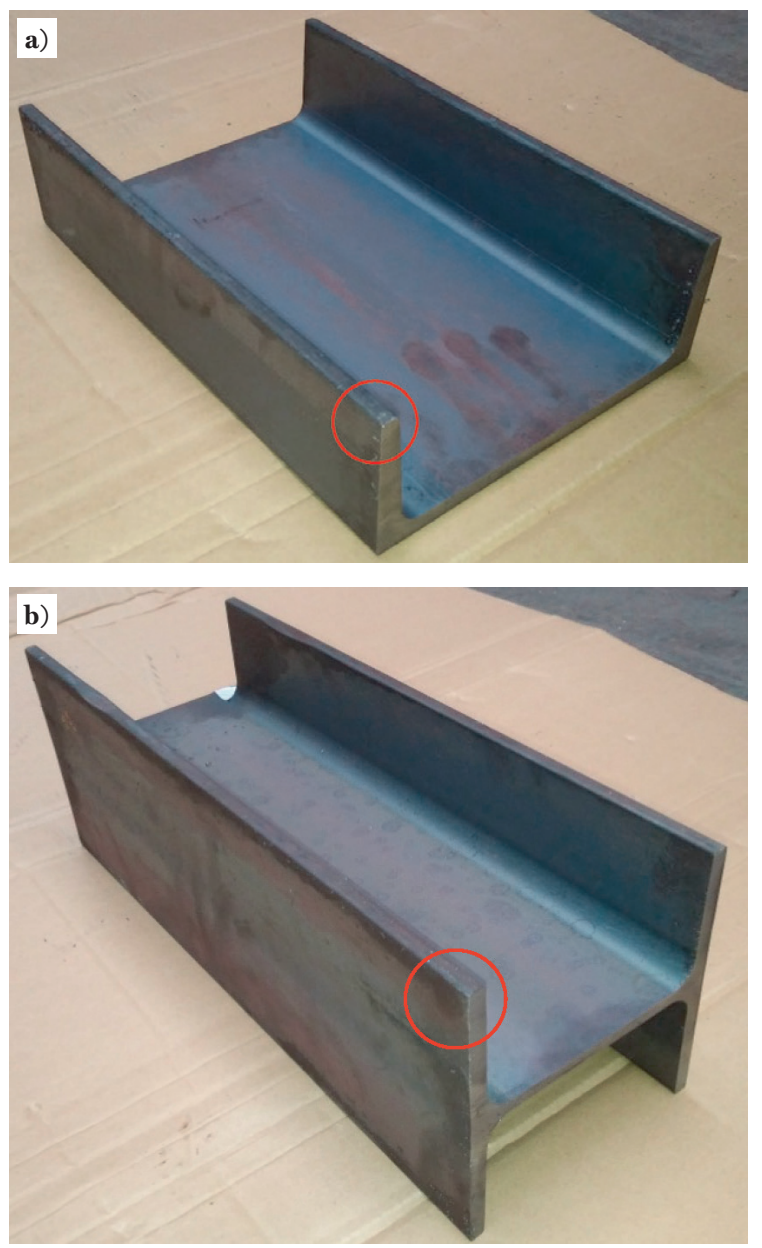

Fig. 2. Sampling for the investigation of microstructure and non-metallic inclusions from the corners of section feet: a) UPN profile, b) HEA profile

Rys. 2. Schemat pobierania próbek do badań mikrostruktury i wtrąceń niemetalicznych z naroży stopek kształtowników: a) profil UPN, b) profil HEA
Figure 3 shows a micrograph and contents of elements of non-metallic inclusions in a sample taken from the corner of a continuous ingot.

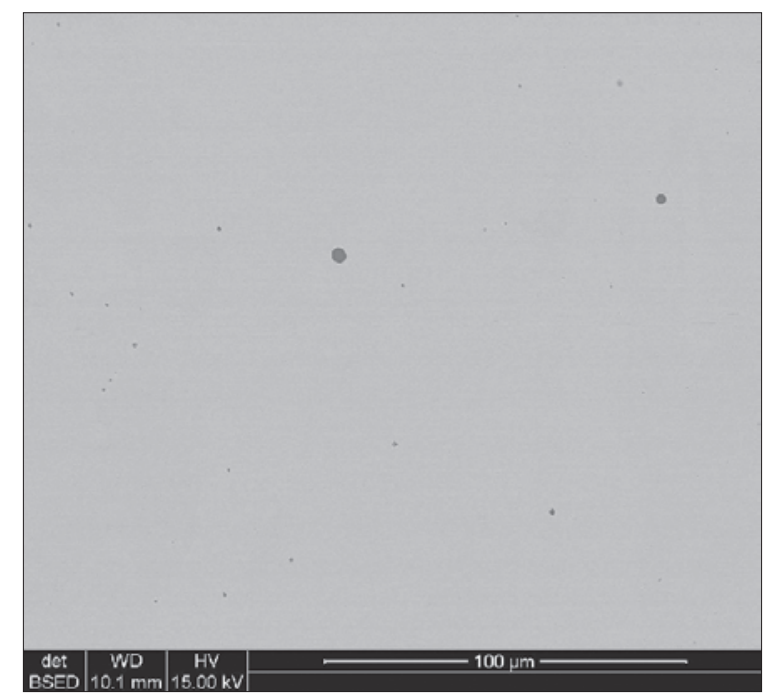

c:ledax32igenesisigenspc.spc 21-May-2018 07:48:19
LSecs : 28

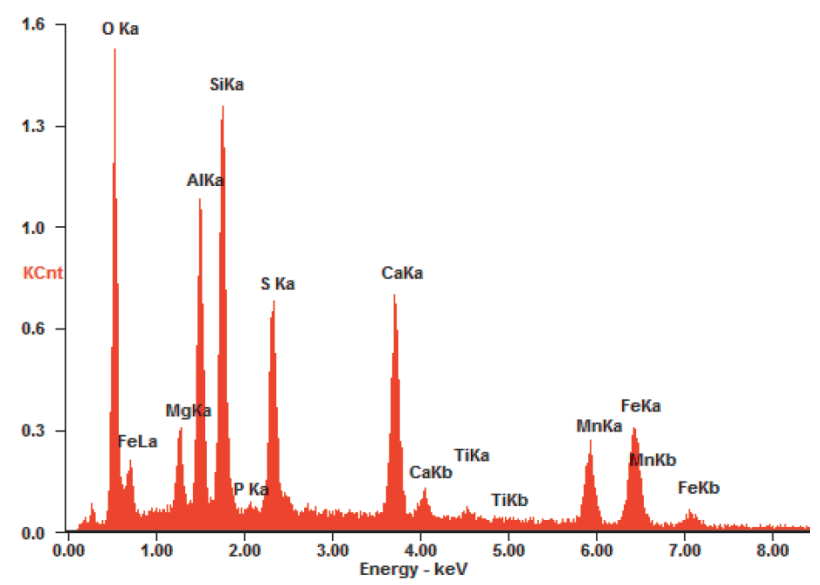

\begin{tabular}{|l|r|r|}
\hline \multicolumn{1}{|c|}{ Item } & Wt \% & At \% \\
\hline $\mathrm{OK}$ & 30.91 & 51.55 \\
\hline $\mathrm{MgK}$ & 2.20 & 2.47 \\
\hline $\mathrm{AlK}$ & 7.97 & 7.88 \\
\hline $\mathrm{SiK}$ & 10.37 & 9.85 \\
\hline $\mathrm{PK}$ & 0.09 & 0.07 \\
\hline $\mathrm{SK}$ & 7.40 & 6.16 \\
\hline $\mathrm{CaK}$ & 12.33 & 8.20 \\
\hline $\mathrm{TiK}$ & 0.97 & 0.54 \\
\hline $\mathrm{MnK}$ & 7.42 & 3.60 \\
\hline $\mathrm{FeK}$ & 20.34 & 9.72 \\
\hline
\end{tabular}

Fig. 3. Chemical composition of the $\mathrm{SiO}_{2} \cdot \mathrm{CaO} \cdot \mathrm{Al}_{2} \mathrm{O}_{3}+\mathrm{MnS}$ nonmetallic inclusion in corner G4 of a steel ingot from heat $\mathbf{5 4 2 1 0 5}$ cast on line 1. Heat with Al deoxidation at the tapping, with the addition of boron, without the Al wire in the mould

Rys. 3. Skład chemiczny wtracenia niemetalicznego typu $\mathrm{SiO}_{2}$. . $\mathrm{CaO} \cdot \mathrm{Al}_{2} \mathrm{O}_{3}+\mathrm{MnS}$ w narożu G4 wlewka ze stali z wytopu 542105 odlanego na linii 1. Wytop z odtlenianiem Al przy spuście, z dodatkiem boru, bez drutu Al do krystalizatora

Figures 4-9 present the results of the investigation of non-metallic inclusions occurring in profiles, and in particular in the areas of surface defects in the profiles. 
Table 7 presents the results of quantitative studies on the purity of steel from research steel heats.

Tables 8 and 9 present the average values of mechanical properties of section samples from test and comparative heats, respectively for the S235JR/S275JR and S355J2 grade.
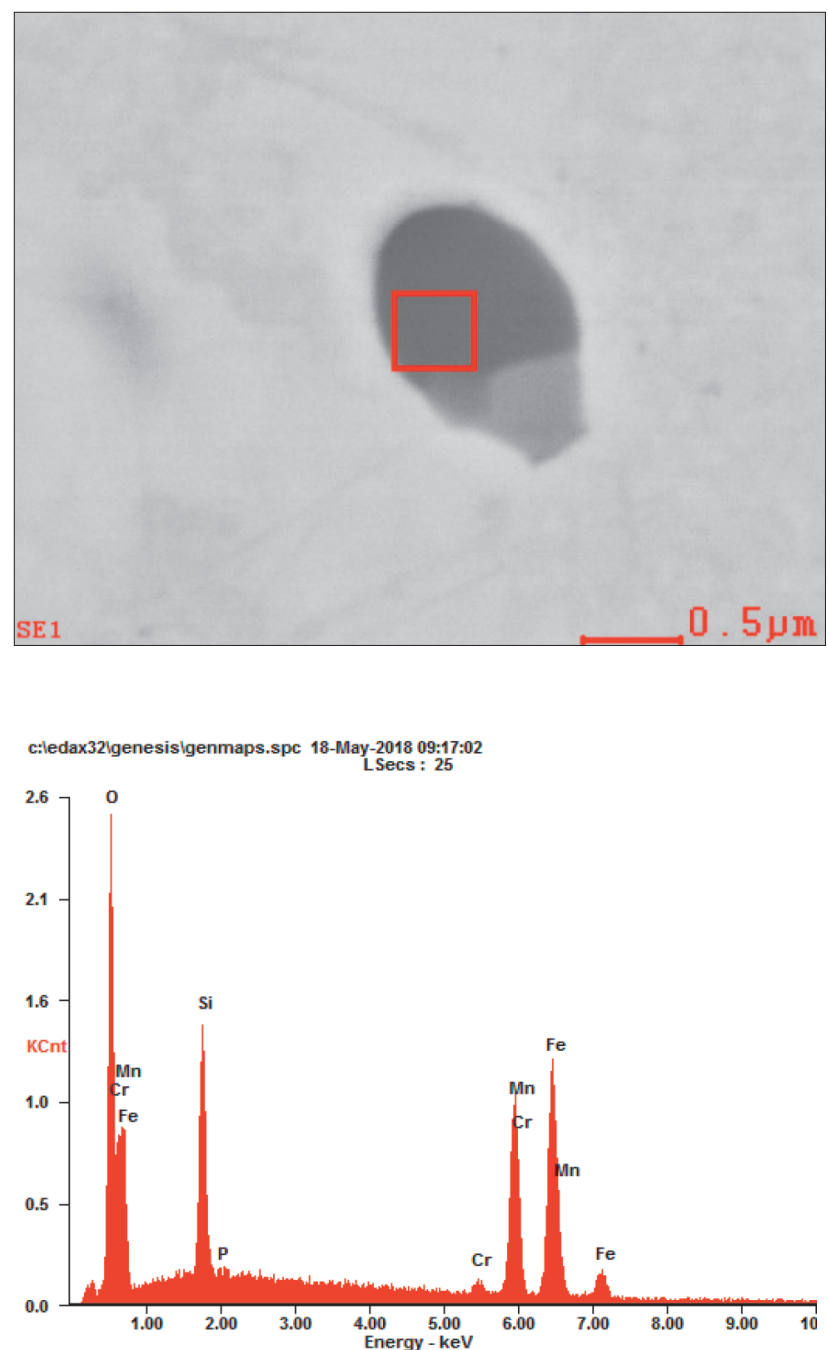

\begin{tabular}{|l|r|r|}
\hline \multicolumn{1}{|c|}{ Item } & Wt $\%$ & \multicolumn{1}{c|}{ At \% } \\
\hline $\mathrm{OK}$ & 10.67 & 27.48 \\
\hline $\mathrm{SiK}$ & 8.12 & 11.91 \\
\hline $\mathrm{PK}$ & 0.35 & 0.47 \\
\hline $\mathrm{CrK}$ & 1.58 & 1.25 \\
\hline $\mathrm{MnK}$ & 32.45 & 24.34 \\
\hline $\mathrm{FeK}$ & 46.82 & 34.55 \\
\hline
\end{tabular}

Fig. 4. Chemical composition of the $2 \mathrm{MnO} \cdot \mathrm{SiO}_{2} \cdot \mathrm{Cr}_{2} \mathrm{O}_{3}$ non-metallic inclusion in the area of the crack in the corner of the section rolled from the ingot from steel from heat 542104 cast on line 1 . Heat with Al deoxidation at the tapping, without the addition of boron, without the Al wire in the mould

Rys. 4. Skład chemiczny wtrącenia niemetalicznego typu $2 \mathrm{MnO}$. $\cdot \mathrm{SiO}_{2} \cdot \mathrm{Cr}_{2} \mathrm{O}_{3} \mathrm{w}$ obszarze pęknięcia $\mathrm{w}$ narożu kształtownika odwalcowanego $\mathrm{z}$ wlewka ze stali $\mathrm{z}$ wytopu 542104 odlanego na linii 1. Wytop z odtlenianiem Al przy spuście, bez dodatku boru, bez drutu Al do krystalizatora

\section{DISCUSSION OF THE RESULTS}

\section{S235/275JR steel grade}

Data presented in Table 5 show that in the case of steel deoxidation with $\mathrm{Al}$ at the tapping (tests No. 3 and 4), lower content of total oxygen in the steel (less than $30 \mathrm{ppm}$ ) was obtained than in the heats without using the addition of $\mathrm{Al}$ at the tapping. In the heats with the addition of $\mathrm{Al}$ at the tapping and with the addition of Fe-B (tests No. 2 and 4), the lowest sulphur content in the finished steel, less than
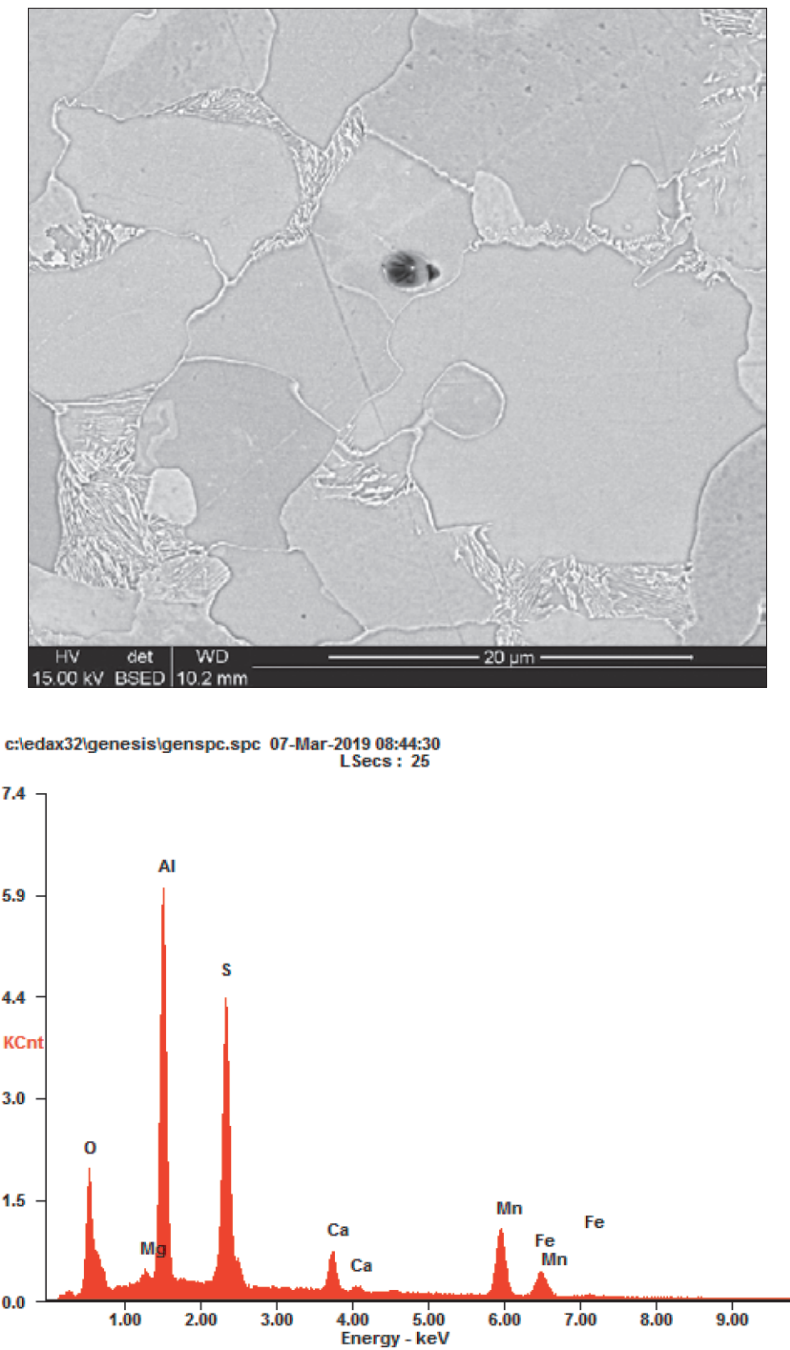

\begin{tabular}{|l|r|r|}
\hline \multicolumn{1}{|c|}{ Item } & Wt \% & \multicolumn{1}{c|}{ At \% } \\
\hline $\mathrm{OK}$ & 26.67 & 44.20 \\
\hline $\mathrm{MgK}$ & 0.76 & 0.83 \\
\hline $\mathrm{AlK}$ & 23.15 & 22.75 \\
\hline $\mathrm{SK}$ & 21.93 & 18.14 \\
\hline $\mathrm{CaK}$ & 4.94 & 03.27 \\
\hline $\mathrm{MnK}$ & 13.50 & 6.52 \\
\hline $\mathrm{FeK}$ & 9.04 & 4.29 \\
\hline
\end{tabular}

Fig. 5. Results of analysis of the chemical composition of the $\mathrm{CaO} \cdot 6 \mathrm{Al}_{2} \mathrm{O}_{3}+\mathrm{MnS}$ non-metallic inclusion in the foot of the S355J2 steel section, from heat 551791 rolled from the ingot cast using $\mathrm{Al}$ in the mould. Heat with Al deoxidation at the tapping, steel with niobium

Rys. 5. Wyniki analizy składu chemicznego wtrącenia niemetalicznego typu $\mathrm{CaO} \cdot 6 \mathrm{Al}_{2} \mathrm{O}_{3}+\mathrm{MnS}$ w stopce ksztattownika ze stali S355J2, z wytopu 551791 odwalcowanego $\mathrm{z}$ wlewka odlanego z zastosowaniem Al do krystalizatora. Wytop z odtlenianiem Al przy spuście, stal z niobem 
$0.010 \%$, was obtained with total aluminium content less than $0.003 \%$, i.e. cast without introducing an $\mathrm{Al}$ wire into the mould.

The results of the examination of non-metallic inclusions indicated that the dominant type of inclusions in the continuous ingot are spherical, complex inclusions of oxysulphides, containing $\mathrm{Al}, \mathrm{Si}, \mathrm{Mg}, \mathrm{Mn}, \mathrm{Ca}, \mathrm{Ti}$ and $\mathrm{S}$, of the $\mathrm{SiO}_{2} \cdot \mathrm{CaO}$. $\cdot \mathrm{Al}_{2} \mathrm{O}_{3}$ type with $\mathrm{MnS}$ precipitated on them during solidification of steel.

The mentioned inclusions are beneficial for the structure of hot-rolled sections. Near the cracks in the section foot, there are fine spherical oxide $\mathrm{FeO} \cdot \mathrm{MnO}$ i $2 \mathrm{MnO} \cdot \mathrm{SiO}_{2} \cdot \mathrm{Cr}_{2} \mathrm{O}_{3}$ inclusions which are the effect of pulling in the slag film and internal oxidation (Fig. 4). In sections rolled from steel cast using the $\mathrm{Al}$ wire in the mould, $\mathrm{Al}_{2} \mathrm{O}_{3}$ inclusions occur in the form of chains (Fig. 6) and clusters (Fig. 7).
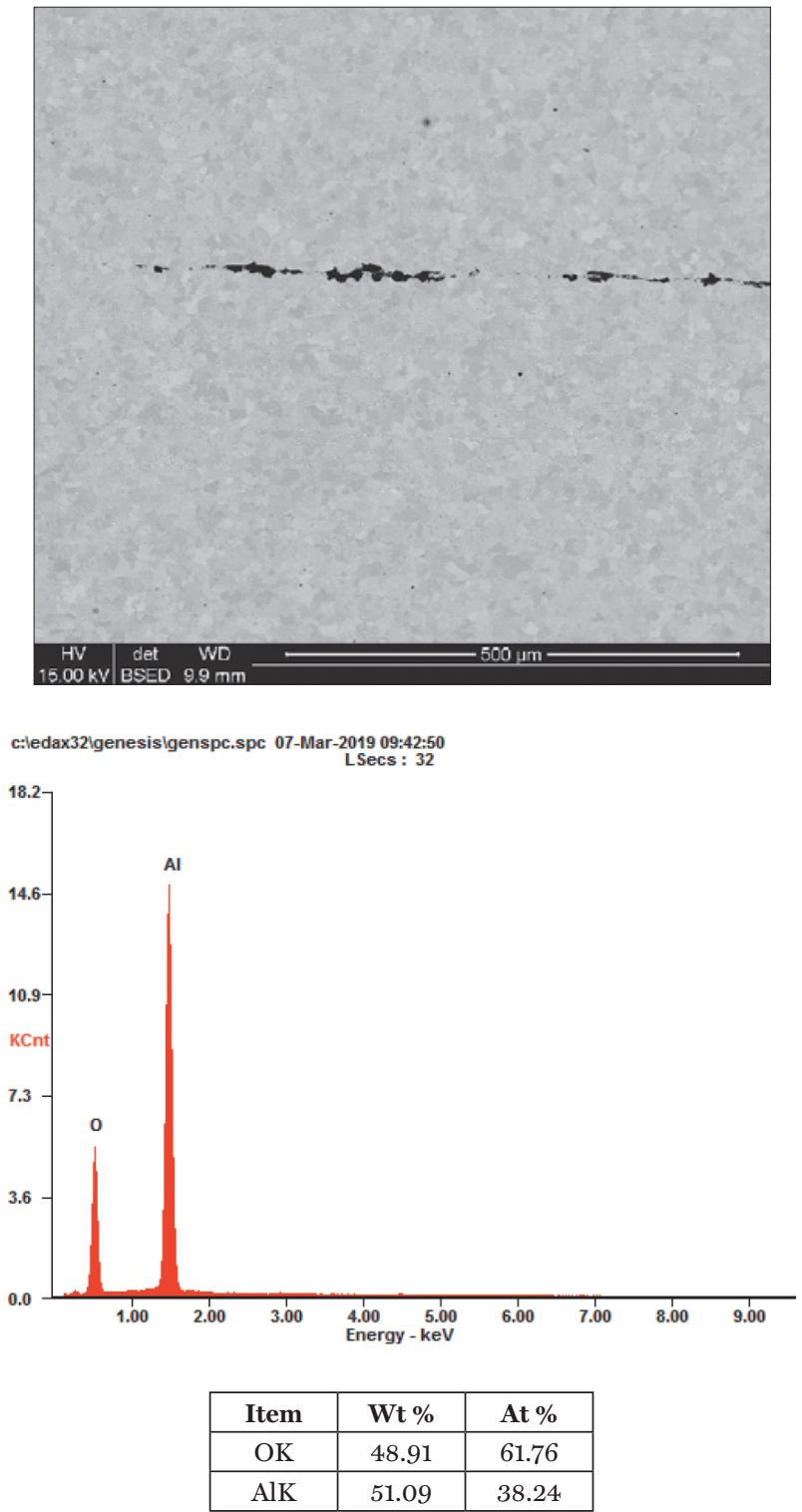

Fig. 6. Results of analysis of the chemical composition of $\mathrm{Al}_{2} \mathrm{O}_{3}$ non-metallic inclusions in the form of a chain, in a sample from the corner of the foot of a S355J2 steel section, from heat 551792 rolled from an ingot cast using $\mathrm{Al}$ in the mould

Rys. 6. Wyniki analizy składu chemicznego wtrąceń niemetalicznych typu $\mathrm{Al}_{2} \mathrm{O}_{3}$ w postaci łańcuszka, w próbce $\mathrm{z}$ naroża stopki kształtownika ze stali S355J2, z wytopu 551792 odwalcowanego z wlewka odlanego z zastosowaniem Al do krystalizatora
Steel deoxidised on the tapping by means of $\mathrm{Al}$ also has a smaller surface area of non-metallic inclusions and a smaller equivalent diameter, i.e. it is characterised by higher purity (Table 7).

The mechanical properties ( $R_{\mathrm{e}}, R_{\mathrm{m}}$ and $A_{5}$ ) of the sections as shown in Table 8 are much higher than required (Table 2). No significant effect of steel deoxidation and casting method - with the $\mathrm{Al}$ wire or without the $\mathrm{Al}$ wire introduced into the mould - on the level of mechanical properties was observed. However, in sections from experimental heats, the average values of $R_{\mathrm{e}}$ and $R_{\mathrm{m}}$ are greater than the average values of $R_{\mathrm{e}}$ and $R_{\mathrm{m}}$ of sections rolled from comparative steel heats. By using a small addition of $\mathrm{Al}$ during the tapping of steel from the furnace and the B micro-additive, which also causes partial deoxidation of the steel and formation of fine complex oxides on which $\mathrm{MnS}$ are favourably precipitated during so-
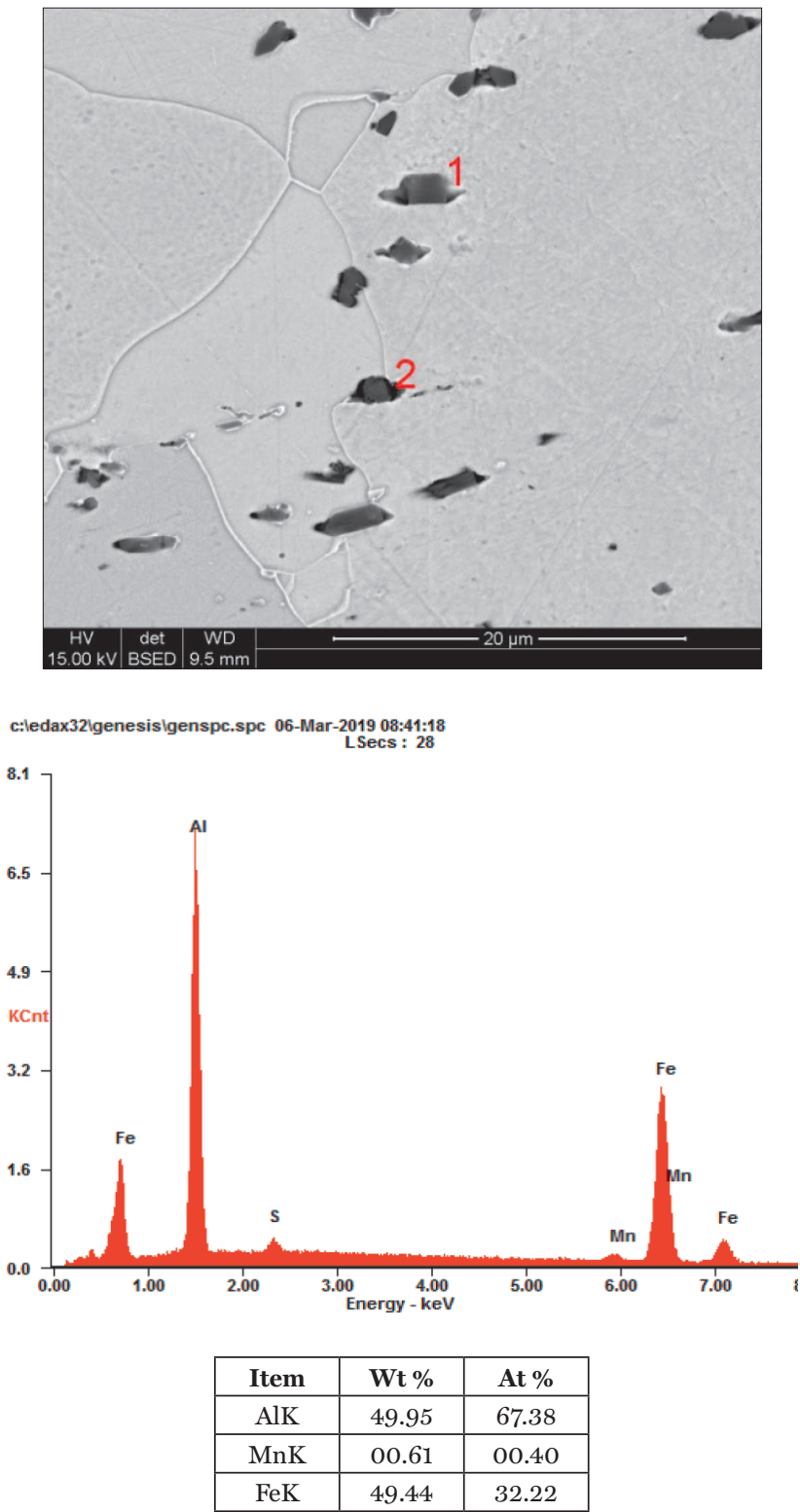

Fig. 7. Results of analysis of the chemical composition of non-metallic inclusions in the form of undissolved $\mathrm{Al}$ in steel, in a sample from the corner of a S235JR/275JR steel section foot, from heat 551811 (comparative heat), with the introduction of Al into the mould

Rys. 7. Wyniki analizy składu chemicznego wtrąceń niemetalicznych w postaci nierozpuszczonego $\mathrm{Al}$ w stali, w próbce $\mathrm{z}$ naroża stopki kształtownika ze stali S235JR/275JR, z wytopu 551811 (wytop porównawczy), z wprowadzaniem Al do krystalizatora 
lidification of the steel in a continuous casting process, the use of wire addition in the mould, and thus defects in continuous ingots, can be successfully eliminated.

\section{S355J2 steel grade}

Data presented in Table 6 show that the use of the technology with steel deoxidation with $\mathrm{Al}$ during tapping (tests No. 7 and 8) allows for obtaining a lower content of total oxygen in the steel (at the level of $30 \mathrm{ppm}$ and less) than in the heats without using the addition of $\mathrm{Al}$ at the tapping.
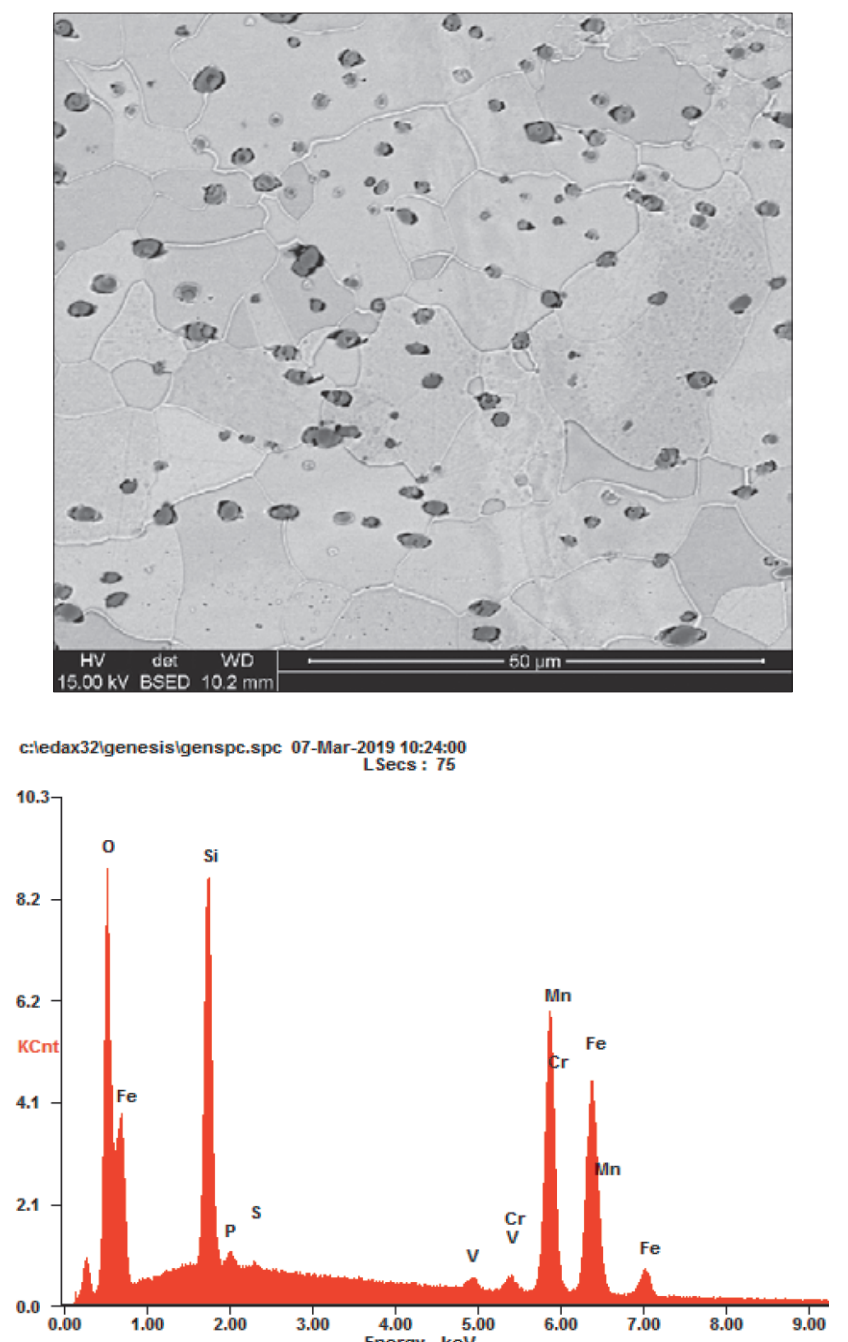

\begin{tabular}{|c|c|c|}
\hline Item & Wt \% & At \% \\
\hline $\mathrm{OK}$ & 24.45 & 49.38 \\
\hline $\mathrm{SiK}$ & 11.01 & 12.67 \\
\hline $\mathrm{PK}$ & 0.43 & 0.45 \\
\hline $\mathrm{SK}$ & 0.15 & 0.15 \\
\hline $\mathrm{VK}$ & 0.87 & 0.55 \\
\hline $\mathrm{CrK}$ & 1.43 & 0.89 \\
\hline $\mathrm{MnK}$ & 24.74 & 14.55 \\
\hline $\mathrm{FeK}$ & 36.90 & 21.35 \\
\hline
\end{tabular}

Fig. 8. Results of analysis of the chemical composition of the nonmetallic inclusion in the form of small clusters of $2 \mathrm{MnO} \cdot \mathrm{SiO}_{2}$ near the crack, in the foot of the section rolled from the S355J2 steel, from heat 552180 (comparative heat), using an Al wire in the mould Rys. 8. Wyniki analizy składu chemicznego wtrącenia niemetalicznego typu drobnych skupisk $2 \mathrm{MnO} \cdot \mathrm{SiO}_{2}$ w pobliżu pęknięcia, w stopce kształtownika odwalcowanego ze stali S355J2, z wytopu 552180 (wytop porównawczy), z zastosowaniem drutu Al do krystalizatora
In steel rolled sections that were cast with steel deoxidation with $\mathrm{Al}$ at the tapping and with the addition of the $\mathrm{Al}$ wire in the mould, there are $\mathrm{CaO} \cdot 6 \mathrm{Al}_{2} \mathrm{O}_{3}$ non-metallic inclusions with $\mathrm{MnS}$ forming during solidification (Fig. 5), $2 \mathrm{CaO} \cdot \mathrm{SiO}_{2} \cdot 3 \mathrm{Al}_{2} \mathrm{O}_{3}$ (Fig. 9) and $\mathrm{Al}_{2} \mathrm{O}_{3}$ chain inclusions (Fig. 6). Near the cracks in the foot, there are finely dispersed $2 \mathrm{MnO} \cdot \mathrm{SiO}_{2}$ inclusions (Fig. 8).

The comparison of the mechanical properties of the sections listed in Tables 9 and 2 shows that the values of $R_{\mathrm{e}}, R_{\mathrm{m}}$
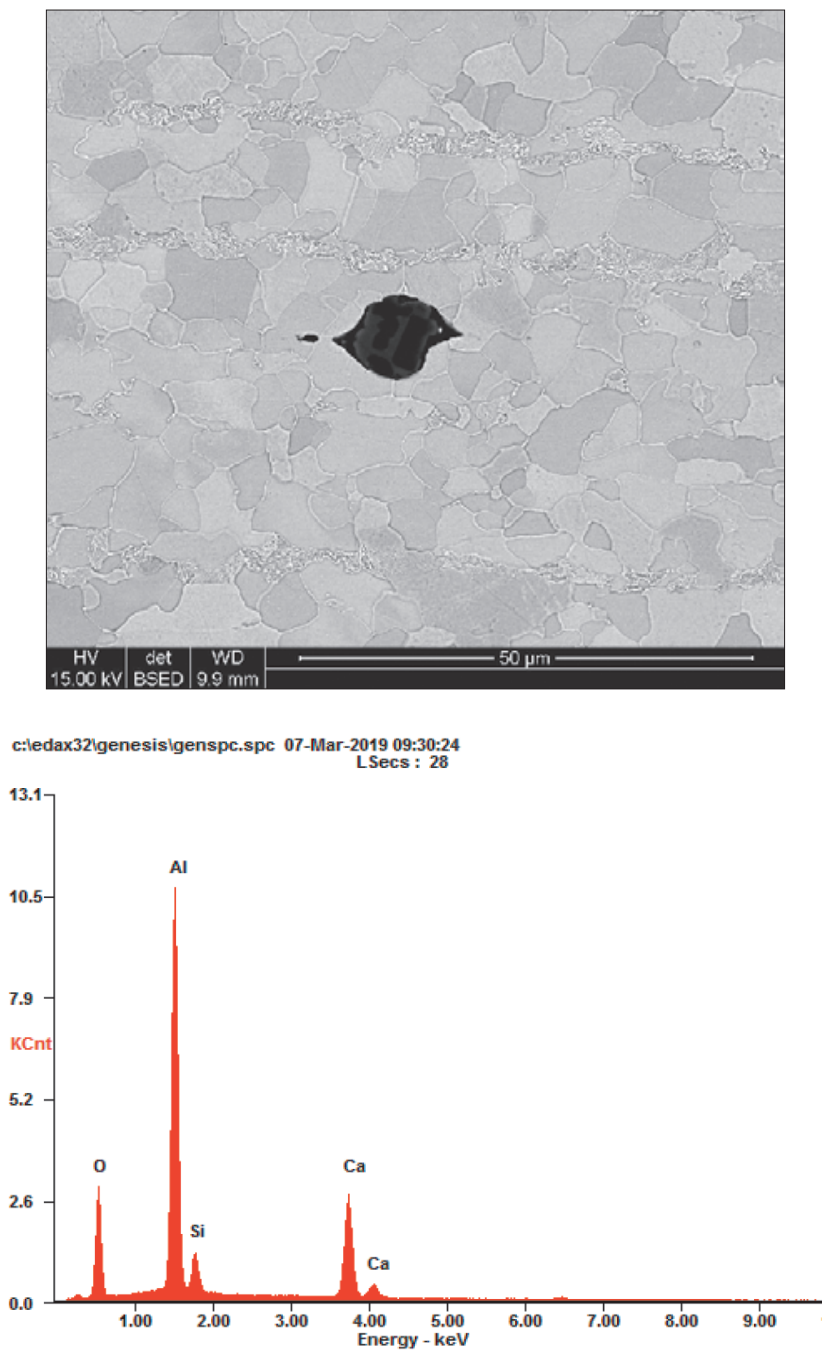

\begin{tabular}{|c|r|r|}
\hline Item & Wt \% & \multicolumn{1}{|c|}{ At \% } \\
\hline $\mathrm{OK}$ & 42.04 & 58.00 \\
\hline $\mathrm{AlK}$ & 34.03 & 27.83 \\
\hline $\mathrm{SiK}$ & 4.24 & 3.33 \\
\hline $\mathrm{CaK}$ & 19.68 & 10.84 \\
\hline
\end{tabular}

Fig. 9. Results of chemical composition analysis of $2 \mathrm{CaO} \cdot \mathrm{SiO}_{2}$. $\cdot 3 \mathrm{Al}_{2} \mathrm{O}_{3}$ non-metallic inclusions in the foot of the $\mathrm{S355J2}$ steel section, from heat 551792 (with $\mathrm{Al}$ deoxidation at the tapping, with $\mathrm{Nb}$ ), rolled from an ingot cast without applying $\mathrm{Al}$ in the mould

Rys. 9. Wyniki analizy składu chemicznego wtrącenia niemetalicznego typu $2 \mathrm{CaO} \cdot \mathrm{SiO}_{2} \cdot 3 \mathrm{Al}_{2} \mathrm{O}_{3} \mathrm{w}$ stopce ksztaltownika ze stali S355J2, z wytopu 551792 (z odtlenianiem Al przy spuście, $\mathrm{z} \mathrm{Nb}$ ), odwalcowanego z wlewka odlanego bez zastosowania Al do krystalizatora 
Journal of Metallic Materials 2019, 71 (1), p. 10-19

Table 7. Results of quantitative studies on non-metallic inclusions in steel from research steel heats Tabela 7. Wyniki badań ilościowych wtrąceń niemetalicznych w stali z badawczych wytopów stali

\begin{tabular}{|c|l|l|c|c|}
\hline $\begin{array}{c}\text { Heat } \\
\text { No. }\end{array}$ & \multicolumn{1}{|c|}{ Steel grade } & \multicolumn{1}{|c|}{ Refining method } & $\begin{array}{c}\text { Surface fraction of } \\
\text { non-metallic inclusions } \\
{[\%]}\end{array}$ & $\begin{array}{c}\text { Average equivalent diameter } \\
\text { of non-metallic inclusions } \\
{[\mu \mathrm{\mu m}]}\end{array}$ \\
\hline 542104 & S235JR/S275JR & $\begin{array}{l}\text { Al deoxidation at the tapping, without B, } \\
\text { without the Al wire in the mould }\end{array}$ & 0.12 \\
\hline 542105 & S235JR/S275JR & $\begin{array}{l}\text { Al deoxidation at the tapping, with B, without } \\
\text { the Al wire in the mould }\end{array}$ & 0.13 \\
\hline 545800 & S235JR/S275JR & $\begin{array}{l}\text { Al deoxidation at the tapping, without B, } \\
\text { without the Al wire in the mould }\end{array}$ & 0.13 \\
\hline 544229 & S355J2 & $\begin{array}{l}\text { Without Al deoxidation at the tapping, without } \\
\text { B, without the Al wire in the mould }\end{array}$ & 0.78 \\
\hline
\end{tabular}

Table 8. Average values of mechanical properties of section samples from test and comparative heats for grade S235JR/S275JR

Tabela 8. Średnie wartości właściwości mechanicznych próbek kształtowników z wytopów badawczych i porównawczych dla gatunku S235JR/S275JR

\begin{tabular}{|c|c|c|c|c|c|c|}
\hline \multirow{2}{*}{$\begin{array}{l}\text { Test } \\
\text { No. }\end{array}$} & \multirow{2}{*}{$\begin{array}{l}\text { Heat } \\
\text { No. }\end{array}$} & \multirow[b]{2}{*}{ Steel refining method } & \multirow[b]{2}{*}{ Casting method } & \multicolumn{3}{|c|}{ Mechanical properties } \\
\hline & & & & $\begin{array}{c}\boldsymbol{R}_{\mathrm{e}} \\
{[\mathrm{MPa}]}\end{array}$ & $\begin{array}{c}\boldsymbol{R}_{\mathrm{m}} \\
{[\mathrm{MPa}]}\end{array}$ & $\begin{array}{c}A_{5} \\
{[\%]}\end{array}$ \\
\hline 1 & $538999 \mathrm{P}$ & traditional & With the introduction of $\mathrm{Al}$ wire into the mould & 337 & 476 & 39.2 \\
\hline 2 & 540351 & $\begin{array}{l}\text { Deoxidation at the tapping } \\
\text { and introduction of } \mathrm{FeB}\end{array}$ & $\begin{array}{l}\text { - On lines } 2 \text { to } 6 \text {, casting with the introduction of } \mathrm{Al} \\
\text { wire into the mould } \\
\text { - On line } 1 \text {, casting without the introduction of } \mathrm{Al} \\
\text { wire into the mould }\end{array}$ & 370 & 495 & 36.6 \\
\hline 3 & 540769 & $\begin{array}{l}\text { Deoxidation at the tapping } \\
\text { and introduction of FeB }\end{array}$ & $\begin{array}{l}\text { - On lines } 2 \text { to } 6 \text {, casting with the introduction of } \mathrm{Al} \\
\text { wire into the mould } \\
\text { - On line } 1 \text {, casting without the introduction of } \mathrm{Al} \\
\text { wire into the mould }\end{array}$ & 341 & 466 & 37.5 \\
\hline 4 & 542105 & $\begin{array}{l}\text { Deoxidation at the tapping } \\
\text { and introduction of } \mathrm{FeB}\end{array}$ & $\begin{array}{l}\text { - On lines } 4 \text { to } 6 \text {, casting with the introduction of } \mathrm{Al} \\
\text { wire into the mould } \\
\text { - On lines } 1 \text { to } 3 \text {, casting without the introduction of } \\
\text { Al wire into the mould }\end{array}$ & 339 & 468 & 38.6 \\
\hline 4 & 542104 & $\begin{array}{l}\text { Deoxidation at the tapping } \\
\text { and no introduction of } \mathrm{FeB}\end{array}$ & $\begin{array}{l}\text { - On lines } 3 \text { to } 6 \text {, casting with the introduction of } \mathrm{Al} \\
\text { wire into the crystalliser } \\
\text { - On lines } 1 \text { to } 2 \text {, casting without the introduction of } \\
\mathrm{Al} \text { wire into the mould }\end{array}$ & 343 & 476 & 38.3 \\
\hline 5 & $\begin{array}{l}544253 \\
544254 \\
544255\end{array}$ & $\begin{array}{l}\text { Without deoxidation at the } \\
\text { tapping and introduction } \\
\text { of } \mathrm{FeB}\end{array}$ & $\begin{array}{l}\text { On lines } 1 \text { to } 6 \text {, casting without the introduction of } \mathrm{Al} \\
\text { wire into the mould }\end{array}$ & 346 & 480 & 36.1 \\
\hline 6 & $\begin{array}{l}545800 \\
545801 \\
545802\end{array}$ & $\begin{array}{l}\text { Deoxidation only at the } \\
\text { tapping }\end{array}$ & $\begin{array}{l}\text { On lines } 1 \text { to } 6 \text {, casting without the introduction of } \mathrm{Al} \\
\text { wire into the mould }\end{array}$ & 346 & 476 & 35.6 \\
\hline 9 & $\begin{array}{l}551812 \\
551813 \\
551814 \\
551815 \\
551816 \\
551817\end{array}$ & $\begin{array}{l}\text { Al deoxidation at the tapping } \\
\text { from a container with alloy } \\
\text { additives }\end{array}$ & $\begin{array}{l}\text { On lines } 1 \text { to } 6 \text {, casting without the introduction of } \mathrm{Al} \\
\text { wire into the mould }\end{array}$ & 349 & 484 & 38.5 \\
\hline $\mathrm{P}$ & 551811 & Standard technology & With $\mathrm{Al}$ wire in the mould & 321 & 456 & 38.7 \\
\hline $\mathrm{P}$ & 552093 & Standard technology & With $\mathrm{Al}$ wire in the mould & 328 & 461 & 37.8 \\
\hline
\end{tabular}

$\mathrm{P}$ - comparative heat per standard technology

Table 9. Average values of mechanical properties of section samples from test and comparative heats for grade S355J2

Tabela 9. Średnie wartości właściwości mechanicznych próbek kształtowników z wytopów badawczych i porównawczych dla gatunku S355J2

\begin{tabular}{|c|c|c|c|c|c|c|c|}
\hline \multirow[b]{2}{*}{$\begin{array}{l}\text { Test } \\
\text { No. }\end{array}$} & \multirow[b]{2}{*}{$\begin{array}{l}\text { Heat } \\
\text { No. }\end{array}$} & \multirow[b]{2}{*}{ Steel refining method } & \multirow[b]{2}{*}{ Casting method } & \multicolumn{4}{|c|}{ Mechanical properties } \\
\hline & & & & $\begin{array}{c}\boldsymbol{R}_{\mathrm{e}} \\
{[\mathrm{MPa}]}\end{array}$ & $\begin{array}{c}R_{\mathrm{m}} \\
{[\mathrm{MPa}]}\end{array}$ & $\begin{array}{c}A_{5} \\
{[\%]}\end{array}$ & $\begin{array}{c}K C V_{\text {average }} \\
{\left[\mathrm{J} / \mathrm{cm}^{2}\right]}\end{array}$ \\
\hline 5 & 544229 & $\begin{array}{l}\text { Without } \mathrm{Al} \text { deoxidation at the } \\
\text { tapping and introduction of } \mathrm{FeB}\end{array}$ & $\begin{array}{l}\text { On lines } 1 \text { to } 6 \text {, casting without the } \\
\text { introduction of } \mathrm{Al} \text { wire into the mould }\end{array}$ & 440 & 542 & 29.1 & 110 \\
\hline 7 & $\begin{array}{l}547831 \\
547832 \\
547833 \\
\end{array}$ & $\mathrm{Al}$ deoxidation only at the tapping & $\begin{array}{l}\text { On lines } 1 \text { to } 6 \text {, casting without the } \\
\text { introduction of } \mathrm{Al} \text { wire into the mould }\end{array}$ & 470 & 590 & 29.6 & 98 \\
\hline 8 & $\begin{array}{l}551791 \\
551792 \\
551793 \\
551794\end{array}$ & $\begin{array}{l}\text { With } \mathrm{Nb} \text { content }-0.02 \% \\
\text { Deoxidation only at the tapping, } \\
\text { Al from a container, with the } \\
\text { remaining additives }\end{array}$ & $\begin{array}{l}\text { - Without } \mathrm{Al} \text { wire in the mould on lines } \\
1,2 \text { and } 3 \\
\text { - With } \mathrm{Al} \text { wire in the mould on lines } 4 \text {, } \\
5 \text { and } 6\end{array}$ & 466 & 571 & 30.5 & 101 \\
\hline $\mathrm{P}$ & 551948 & Standard technology & With $\mathrm{Al}$ wire in the mould & 476 & 570 & 29.2 & 139 \\
\hline $\mathrm{P}$ & 552180 & Standard technology & With $\mathrm{Al}$ wire in the mould & 466 & 566 & 30.0 & 83 \\
\hline
\end{tabular}

$\mathrm{P}$ - comparative heat per standard technology 
and $A_{5}$ of sections rolled from experimental heats are much higher than required. As in the case of S235/275JR steel sections, no significant effect of steel deoxidation and casting method - with the $\mathrm{Al}$ wire or without the $\mathrm{Al}$ wire in the mould - on the level of mechanical properties was observed. The addition of boron ( $\mathrm{Fe}-\mathrm{B}$ ) has a large impact on $\mathrm{KV}$ values, both in the heats without introducing the $\mathrm{Al}$ wire into the mould and without deoxidising the steel with $\mathrm{Al}$ at the tapping (test No. 5, Table 9). Steel treated with the $\mathrm{Al}$ wire introduced into the mould in comparative melts, according to standard technology, is characterised by a large, about $50 \%$ spread of the KV value between the heats (Table 9).

By using a small addition of $\mathrm{Al}$ during the tapping of steel from the furnace and the $\mathrm{V}, \mathrm{Nb}$ and $\mathrm{B}$ micro-additive, which also causes partial deoxidation of the steel and formation of fine complex oxides on which $\mathrm{MnS}$ are favourably precipitated during solidification of the steel in a continuous casting process, the use of wire addition in the mould, and thus defects in continuous ingots, can be successfully eliminated. In the future, it is necessary to consider the use of $\mathrm{Zr}$ microadditive for deoxidation, which is a deoxidiser as strong as $\mathrm{Al}$, but it forms very fine $\mathrm{ZrO}_{2}$ inclusions, with lattice constant similar to MnS, contributing to numerous precipitations of $\mathrm{MnS}$ inclusions on them during solidification, on which fine-grained acicular ferrite nucleates. This microstructural component increases the impact and weldability properties of rolled sections.

No surface defects, caused by exogenous $\mathrm{Al}_{2} \mathrm{O}_{3}$ inclusions coming from the wire introduced into the mould were found in sections from experimental heats of both steel grades.

\section{SUMMARY AND CONCLUSIONS}

The results of experimental studies on the optimisation of secondary metallurgy technology in a ladle for partial or total elimination of steel treatment with an $\mathrm{Al}$ wire in the mould and elimination of surface defects in the sections caused by $\mathrm{Al}$ wire treatment allow the following conclusions: 1. No surface defects, caused by exogenous $\mathrm{Al}_{2} \mathrm{O}_{3}$ inclusions coming from the wire introduced into the mould were found in sections from experimental heats of both steel grades.

2. The S235JR/S275JR and S355J2 steel cast using predeoxidation with aluminium introduced into the stream together with other additives can be cast without the use of an $\mathrm{Al}$ wire in the mould, without risking surface defects, such as punctures or slag inclusions, in the sections.

3. The application of an $\mathrm{Al}$ wire in the mould in the continuous casting process significantly increases the impact strength of S355J2 steel sections containing vanadium and niobium microadditives.

4. Surface defects of the sections due to the excessive accumulation of $\mathrm{Al}_{2} \mathrm{O}_{3}$ inclusions just below the surface of the ingot mainly result from disturbances in the introduction of the $\mathrm{Al}$ wire into the mould.

5. Limiting the occurrence of discontinuities on section feet can be achieved mainly through the improvement of the technique of dosing an $\mathrm{Al}$ wire into the mould, as well as by introducing boron into the steel, the oxidation of which during the continuous casting process will reduce the melting point of the slag film and its easy separation from the steel in the mould without absorbing $\mathrm{Al}_{2} \mathrm{O}_{3}$ slag film into the continuous ingot.

6. The addition of boron (Fe-B) largely affects the KCV values, both in the heats without the introduction of the $\mathrm{Al}$ wire into the mould and without deoxidation of the steel with $\mathrm{Al}$ at the tapping.

7. In the future, it is recommended to study the use of $\mathrm{Zr}$ micro-additive for deoxidation of steel, which is a deoxidiser as strong as $\mathrm{Al}$, but it forms very fine $\mathrm{ZrO}_{2}$ inclusions, with lattice constant similar to $\mathrm{MnS}$, contributing to numerous precipitations of $\mathrm{MnS}$ inclusions on them during solidification, on which fine-grained acicular ferrite nucleates. This microstructural component increases the impact and weldability properties of rolled products made of Al-free steels.

The results included in the publication were obtained as part of the research carried out in the project within the INNOSTAL sectorial program financed from funds under the first priority axis "Support for Conducting R\&D by Enterprises" Measure 1.2 "Sectoral R\&D Programmes" of the Intelligent Development Operational Programme 2014-2020.

Agreement No. POIR.01.02.00-00-0179/16. co-financed by the European Regional Development Fund.

\section{REFERENCES}

[1] P. Presoly, G. Xia, P. Reisinger, C. Bernhard. Continuous Casting of Hypo-peritectic Steels: Mould Thermal Monitoring and DSC-analysis. BHM, 2014, 159 (11), p. 430-437.

[2] M.L. Fares, A. Darsouni, J. Le Coze. Comparing the Hot Ductility Behaviour of Low-Carbon Microalloyed Nb-V-Ti Steels during Two Thermal Cycling Routes: Solutionizing and Precipitation Treatments. Steel Research Int. 2015, 86 (9), p. 1090-1103.

[3] R. Bruna, G. Ebri, A. Cerliani, J. Moriconi, C.I. Garcia. A CostEffective Approach to the Development of High-Strength-High-
Toughness NbVTi-Based HSLA Steels for Agricultural and Heavy Transportation Industries. Iron and Steel Technology, 2018, 15 (4), p. 66-72.

[4] R. Lino, L. Barbosa, J. Prado, F. Oliveira, L. Reis, R. Barbosa. Development of High-Strength Microalloyed Rebar. Iron and Steel Technology, 2018, 15 (8), p. 120-128.

[5] J. Campbell. Melting, Remelting and Casting for Clean Steel. Steel Research Int., 2017, 88 (1), p. 1-13. 